UDC 654.19(075.8)

BBC 76.031

\title{
Three faces of Trickster in modern politics: Donald Trump, Alexey Navalny and Julian Assange
}

\author{
Julia A. Chernenko \\ National Research University "Higher School of Economics" \\ 20 Myasnickaya St., Moscow, 101000, Russian Federation
}

Concerning current situation and media ecology actors of political communication should be flexible to adapt their PR strategies to the fluid agenda and mosaic thinking of their audience. The following article aims to describe one of the most multi-faceted archetypes used in political communications - the archetype of Trickster. Using the method of case study, the author argues that concerning information society and digital culture Trickster gains better opportunities to hold a successful PR campaign and to build a solid political image. The author describes the following archetype with the address to three figures of international and Russian politics that appear in agenda in 2010-2018: Donald Trump, Alexey Navalny, and Julian Assange.

Using the notions of narrative politics and theory of archetypes, the author concludes vast potential of Trickster archetype in modern political communications, that can be even stronger than the traditional images of Hero or Wise Ruler. The author assumes that Trickster figure in modern politics became wider than classical image of Fool and Jester and now is also widely used in the aspects of "noble thug" and Shaman.

Keywords: Trickster; post-truth; USA; Russia; Wikileaks; political communication; information society; social media

\section{Introduction}

The traits and results of "mediatization of politics" are widely known and described by Russian and foreign scholars. These are the widespread of fake news, that are often more impressing and eye-catching than the actual news, the growing popularity of social media such as Instagram, Twitter or Facebook as a tool for political communication, the falling of interest to the "pure" political news as it is $[1 ; 2]$. Thus actors of political communications have to find new ways to gain an audience and especially millennials. The era of so-called "post-truth politics" challenges new tools and paces, and the most common of them is the technic of

(C) Chernenko J.A., 2019

This work is licensed under a Creative Commons Attribution 4.0 International License https://creativecommons.org/licenses/by/4.0/ 
storytelling with the elements of shared narratives (or - in Russian academic tradition - migrating plots) $[3 ; 4]$.

One of the "greatest showmen" between the masks and archetypes is the figure of Trickster. Jungian follower and the creator of guides for professional writers Christopher Vogler describes Trickster as one of the most popular heroes of stories and even claims that Trickster is one of the character archetypes that "are indispensable tools of the trade. You can't tell stories without them" [5. P. 26]. Classic Trickster has a variety of sides and functions. Following Vogler, the main is to embody "the energies of mischief and desire for change" [5. P. 77]. This flexibility gives many opportunities to the one who dares to play the Trickster role. A number of scholars described the functions and distinctive features of Trickster: starting from C.G. Jung with his concept of analytical psychology, to his followers J. Campbell ("A Hero with Thousand Faces") and C. Vogler ("The Writer's Journey"), or authors with alternative views on the character (for example, "The Female Trickster" by R.S. Tannen), as well as several Russian modern literary and communication scholars - Yu. Chernyavskaya ("Trickster, or Journey to Chaos") [6], A. Gavrilov ("On the definition of Trickster and his importance in socio-cultural reality"), E. Meletinskiy ("Analytical psychology and the problem of origin of archetypical plots"), S. Shomova ("Jester, Petrushka, Fool...”) and others. Following these ideas, we can compose a list of primary advantages of using the Trickster archetype in political communication:

1) freedom to point out the problems, follies and the mistakes (e.g. of the existing government);

2) domination in the news agenda;

3) flexibility in speech and topics of commentary (naturally, Trickster can comment on everything, whether he or she is expert on the issue or not);

4) opportunity to take the Trickster's words back (or even to say that he or she did not make a specific claim or offer particular idea) [7].

As the aim of this article is to describe the three faces of Trickster, the research is based on qualitative methodology and applies the method of case study. Within a framework of this article, we will go through three cases to deconstruct the political communications and describe the strategy of three types of Trickster: Classic Trickster (Fool, Jester), Trickster as Hero (the type of Robin Hood) and Trickster as Shaman (the type of Ratcatcher/Pied Piper).

We should also make the final note on the theoretical approach on the topic that one of the most mighty cultural heroes of the Christian religion - Jesus Christ may also be concerned as a Trickster for his functions and actions (the type of Ratcatcher). Keeping this in mind, shall we analyze the images and communicative strategies of the heroes of this article: Donald Trump, Alexey Navalny and Julian Assange.

\section{Donald Trump: Classic Trickster?}

When we look at the communication of Donald Trump, there is no doubt that he is used to the tools of Trickster game: the list of people, things and companies that Trump has insulted at his Twitter already counts more than 590 names [8]. 
His speech does not have any values, such as moral or ethic (e.g. the offer to penalize women for abortions, the humiliation of Miss of the World that she is too overweight for this rank, approval of Orlando gunfire, etc.) [9]. Donald Trump is famous for his nonsense and preposterous claims that seems to strengthen his reputation as Trickster: one of the brightest examples, now considered as the standard of posttruth claims, is the idea of Trump that Barack Obama and Hillary Clinton founded ISIS and are the Heads of this movement [10].

In the biography of Trump [11] we can find the motif of classic Trickster initiation: following this narrative, Trump decided to start his political career and become a candidate for the presidency after the public offense from Barack Obama in 2011. During the high-level meeting, that Donald Trump visited with his wife, Barack Obama reminded the situation with the "Birthers" movement, that Trump had favored. The offended media-tycoon left the route right after the speech of Obama. If we look at this story, we can see the template of shared narrative for the Trickster archetype initiation. One of the most famous stories within this pattern is the story about Loki, the Scandinavian God of the Lie, who was offended by the Odin during the feast of Gods - this mischief of Loki ended with the Death of Baldr. The other famous motif is from the fairy tales: that is the scheme when the hero is cursed by the witch or wizard, who was not invited to the feast (the beginning of the "Sleeping Beauty" is the classic example).

Hillary Clinton, as the political opponent of Donald Trump, also tried to highlight him as the Classic Trickster - the Fool and the Jester. While the motif of the game is one of the central for Trickster, from the Twitter of Hillary Clinton we can see the posts with the theme of play ("our economy is not a game", "won't let him dice the future of our children") [12]. The mass media, such as "The Economist", also use the motifs of Trickster while showing Donald Trump as a capricious child with the Red Button [13]. During the Debates Hillary Clinton tried to use the strategy of a mother, who communicates with the child, nasty and rebellious ("Well, Donald, I know you live in your own reality, but that is not the facts", etc.) [14].

And even despite this Trickster image and controversial communication strategy, Trump managed to win the election race in November 2016. One of the possible reasons for this result may be the complexity of Trickster archetype, its ambivalence in the reception of the mass unconsciousness. Being the Fool on one side, on the side Trickster is the main hero to say the "forbidden" truths that are kept deep inside the ordinary community member's consciousness. This archetype has the power to disrupt the spiral of silence and speak directly about the problems, without any taboo or moral rules. That is why Trickster is not only the Fool, but also the Ratcatcher, someone to follow.

Of course, we can't say, that Trump had won the election only because of the Trickster image. But this makes more understandable some irrational motifs for the desire of various politicians and media outlets to draw parallels between Donald Trump and Adolf Hitler, one of the most famous political Ratcatchers in the world history [15]. The model of revealing the deeply rooted and not "politically correct" ideas, that will answer the suppressed unconscious meanings of citizens, is generally the same. 


\section{Alexey Navalny: Robin Hood}

The other variation of Trickster archetype may be characterized by the definition of Christopher Vogler as the Heroic Trickster, or Trickster as the Hero. This type is widely known as Robin Hood, or "noble thug" with the examples of Captain Blood, Vladimir Dubrovskiy, Zorro and others. With the right communicative strategy this image can effectively use both the advantages of Trickster and Hero archetypes. Moreover, the contradiction to the Hero will work not only against him but for him too.

The best example of this image is Russian opposition politician Alexey Navalny, who has got the reputation of the fighter against corruption and the illegal actions of Russian politicians. Being the alternative candidate for the post of Mayor of Moscow, Alexey Navalny used every action against him as the chance to get more publicity and popularity. He has built his strategy on direct meetings with the citizens, showing and acting as the "one of us", partisan methods of agitation (such as stickers on bags or cubes at the streets), as well as media scandals (one of the most famous was about the assault of the "Navalny flat", where the agitation materials were stored). Combining this with the "fighter against corruption" stories about the flats of Sobyanin's daughter, Navalny managed to get 27,3\% of votes at the election day ( $8^{\text {th }}$ September, 2013) instead of 3\% that was stated by Levada Center in the beginning of the campaign. In addition to this, he gained the sympathy of a particular type of the electorate, the rebellious adolescents, who were ready to follow the Robin Hood romanticism. Providing the chance of enlargement for the electorate (the symbolical place of Robin Hood's Goodfellow), Navalny could create a team of support among the vast audience.

\section{Julian Assange: Pied Piper or...?}

The third Hero of this article is the founder and the Head of WikiLeaks company, Julian Assange. Strictly he is not a direct politician, but can be concerned as a political actor since the strategy of WikiLeaks involves the company in a political agenda (from 2016 WikiLeaks is accused to affect the presidential elections in the United States, 2016, and presidential elections in France, 2017; it has also made leaks about Russian politicians). The leaks itself can be considered as the mischiefs of Trickster, as they make instability and attack the existing political situation by revealing the political information that was private or unknown before. The actions of Assange give the political opponents of his victims power to manipulate with the information that was revealed - like Donald Trump did during the debates with Hillary Clinton.

Assange himself possesses his leaks as the fight against lying political elites and plays the role of Robin Hood, who gives tons of information to the ordinary people, so that they can make their own opinion about the situation. In this light the acquisitions in rape may look like reasons to make him shut his mouth and do not interfere with the political agenda from the side of elites. The situation of Assange corresponds well with his communicative strategy of not giving any inter- 
views (the few exceptions are the chosen journalists), hiding his residence and playing paranoia ("The first time I met Assange, he was convinced a sniper was targeting him through the windows of a conference centre. A few hours later, he was happily typing in front of the same windows") as well as playing the child in communication with the journalists ("I need some mothering. Someone to make me chicken noodle soup and bring me cookies in bed") [16]. The last interesting side of Assange's character is the belief in his solemnity, noted by journalist Heather Brooke. The journalist tells the story as follows:

"I later heard from two other women who said Assange pulled the same "poor little lost boy" trick on them in an attempt to finagle his way into their homes. I said that was not how I conducted interviews. He complained that I didn't have a maternal instinct, adding in drama-queen fashion: "I have two wars to stop".

I replied: "Yeah, it's a tough life being a messiah." His response left me speechless: "Will you be my Mary Magdalene, Heather? And bathe my feet at the cross." [16].

In this case we can see the other, third face of Trickster, Messiah with the allusions to Jesus Christ. The paradox of archetypes is that the double side of Trickster as an image provides great opportunities with the capacity to make delicate adjustments during the acts of political communication. The person who uses Trickster archetype in his communication gains power to build a wide range of images from the Fool to the Messiah. What is the psychological gap between them, how to measure it and how to assure the multifaceted perception of the person? These may be the questions that would lead to the understanding of the reasons of popularity of "monstrous" ideas and figures, such as Adolf Hitler and Iosif Stalin, the famous "Ratcatchers" of the history.

\section{Conclusion}

The storytelling as a method of political communication is still studied by the scholars, although widely used practically. Questionless, we can not claim that this technique and the actions through narratives will affect the perception directly, as the political communication in digital era is far more complicated. We also can not say that this factor will be the major in decision making. But the ability of narratives to form beliefs of the potential electorate, to build the image and to have some effects on political communication is obvious. Studying the limits of narrative paradigm and its power [17], mechanisms of its functioning and making impact [18], measuring the strength of this particular impact and developing opportunities to defend against the storytelling as the tool of information war - these are the possible horizons for the branch of communication and media studies, that are unreachable without deep collaboration and cross-disciplinary work, including literary studies (narrative theory), psychology (studies of perception and irrational tools) [19] and political studies. 


\section{References}

[1] Wimmer J. et al. (Mis)Understanding Political Participation: Digital Practices, New Forms of Participation and the Reneval. New York: Taylor and Francis, 2018.

[2] Shomova S.A. Ot misterii do strit-arta. Ocherki ob arhetipah kul'tury v politicheskoj kommunikacii [From the mystery to street-art. Notions on the archetypes of culture in political communication]. Moscow: National Research University "Higher School of Economics", 2016.

[3] Mayer F.W. Narrative politics: stories and collective action. New York: Oxford University Press, 2014.

[4] Chernenko J. Political Storytelling in Digital Culture: A Tool for Post-Truth Politics? // Communications. Media. Design. 2017. Vol. 2. No. 1. https://cmd-journal.hse.ru/article/ view/6837 (accessed: 01.06.2019).

[5] Vogler C. The Writer's Journey: Mythic Structures for Writers. Studio City: Michael Wiese Productions, 2007.

[6] Chernjavskaja Ju.V. Trikster, ili Puteshestvie v Haos [Trickster, or the Journey to Chaos] // Chelovek. 2004. No. 3. Pp. 37-52.

[7] Shkurko N.S. Ispol'zovanie arhetipov geroja i trikstera v sozdanii obrazov politicheskih dejatelej [The usage of the archetypes of Hero and Trickster in the creation of image of political actors] // Young Scientist. 2014, April. No. 4(07). Pp. 12-15.

[8] Lee J.C., Quealy K. The 598 People, Places and Things Donald Trump Has Insulted on Twitter: A Complete List // New York Times. 2019, 24 May. https://www.nytimes.com/ interactive/2016/01/28/upshot/donald-trump-twitter-insults.html?ref=politics\&_r=2 (accessed: 04.06.2019).

[9] Official Twitter of Donald Trump. https://twitter.com/realdonaldtrump (accessed: 04.06.2019).

[10] Siddiqui S. Donald Trump calls Barack Obama the Founder of ISIS // The Guardian. 2016, 11 August. https://www.theguardian.com/us-news/2016/aug/11/donald-trumpcalls-barack-obama-the-founder-of-isis (accessed: 04.06.2019).

[11] Soloviev V., Klepikova E. Donald Trump. Fight for the White House. Moscow: RIPOL Classic Publ., 2016.

[12] Official Twitter of Hillary Clinton. https://twitter.com/hillaryclinton (accessed: 04.06.2019).

[13] The Economist. 2018, 11 January. https://www.economist.com/ printedition/2018-01-13 (accessed: 04.06.2019).

[14] Blake A. The First Trump Clinton Presidential Debate Transcript Annotated // The Washington Post. 2016, 27 September. https:/www.washingtonpost. com/news/the-fix/wp/2016/ 09/26/the-first-trump-clinton-presidential-debate-transcript-annotated/ (accessed: 04.06.2019).

[15] Auslander S. Don't compare Donald Trump to Adolf Hitler. It belittles Hitler // The Washington Post. 2016, 13 September. https://www.washingtonpost.com/posteverything/ wp/2016/09/13/dont-compare-donald-trump-to-adolf-hitler-it-belittles-hitler/?utm _ term=.4ff82af31 de5 (accessed: 04.06.2019).

[16] Ball J., Rusbridger A., Brooke H. et al.Who is Julian Assange? By the people who know him best // The Guardian. 2012, 24 August. https://www.theguardian.com/media/2012/ aug/24/who-is-julian-assange (accessed: 04.06.2019).

[17] Booker C. The seven basic plots: why we tell stories. New York: Continuum, 2004.

[18] Lucaites J.L., Condit C.M. Re-constructing Narrative Theory: A Functional Perspective // Journal of Communication. 1985. Vol. 35. No. 4. Pp. 90-108.

[19] Thompson R., Haddock G. Sometimes stories sell: when are narrative appeals most likely to work? // European Journal of Social Psychology. 2012. Vol. 42. No. 1. Pp. 92-102. 


\title{
Article history:
}

Received: 28 July 2019

Revised: 10 August 2019

Accepted: 12 September 2019

\section{For citation:}

Chernenko J.A. (2019). Three faces of Trickster in modern politics: Donald Trump, Alexey Navalny and Julian Assange. RUDN Journal of Studies in Literature and Journalism, 24(4), 756-764. http://dx.doi.org/10.22363/2312-9220-2019-24-4-756-764

\section{Bio note:}

Julia A. Chernenko, Ph.D. in Philology, expert at the Laboratory for Educational and Youth Journalism, lecturer in the School of Media, Faculty of Communications, Media and Design, National Research University “Higher School of Economics”. E-mail: juchernenko@ hse.ru

Научная статья

\section{Три лика Трикстера в современной политике: Дональд Трамп, Алексей Навальный и Джулиан Ассанж}

\author{
Ю.А. Черненко
}

\begin{abstract}
Национальный исследовательский университет «Высшая школа экономики» Российская Федерация, 101000, Москва, ул. Мясницикая, 20
\end{abstract}

Актуальность представленной статьи обусловлена многократно возросшим в условиях политики постправды интересом акторов политической коммуникации к архетипическому образу Трикстера. Автор статьи последовательно показывает преимущества и возможности политиков-Трикстеров в условиях цифровой культуры и информационного общества, когда происходит повсеместная медиатизация политики. Цель исследования проанализировать разные варианты использования образа Трикстера в политической коммуникации в России и мире на примерах трех часто встречающихся в новостной повестке 2010-2018 гг. политических фигур: Дональда Трампа, Алексея Навального и Джулиана Ассанжа. В исследовании автор использует материалы социальных медиа, в которых ведут политическую коммуникацию указанные акторы, журналистский контент и материалы СМИ, интервью для изданий.

Автор статьи приходит к выводу, что Трикстер в современной медиасреде обладает куда большим коммуникационным потенциалом, чем более традиционные архетипы Героя и Мудрого Правителя. Подчеркивается, что неоднозначность трактовки образа Трикстера, хотя и осложняет применение этого образа политическими акторами, может стать одним из факторов, благодаря которым деятель добивается успеха в политической борьбе. На материалах политической коммуникации продемонстрированы три варианта обращения к образу Трикстера: классический Трикстер (Шут, Дурак), Трикстер как Герой (Робин Гуд) и Трикстер как Шаман (Крысолов и Мессия).

Ключевые слова: трикстер; постправда; США; Россия; WikiLeaks; политическая коммуникация; информационное общество; социальные медиа 


\section{Список литературы}

[1] Wimmer J. et al. (Mis)Understanding Political Participation: Digital Practices, New Forms of Participation and the Reneval. New York: Taylor and Francis, 2018.

[2] Шомова C.A. От мистерии до стрит-арта: очерки об архетипах культуры в политической коммуникации. М.: Высшая школа экономики, 2016.

[3] Mayer F.W. Narrative Politics: Stories and Collective Action. New York: Oxford University Press, 2014.

[4] Черненко Ю.А. Political Storytelling in Digital Culture: A Tool for Post-Truth Politics? // Коммуникации. Медиа. Дизайн. 2017. Т. 2. № 1. URL: https://cmd-journal.hse.ru/ article/view/6837 (дата обращения: 01.06.2019).

[5] Vogler C. The Writer's Journey: Mythic Structures for Writers. Studio City: Michael Wiese Productions, 2007.

[6] Чернявская Ю.В. Трикстер, или Путешествие в Хаос // Человек. 2004. № 3. С. 37-52.

[7] Шкурко Н.С. Использование архетипов Героя и Трикстера в создании образов политических деятелей // Молодий вчений. 2014, апрель. № 4 (07). С. 12-15.

[8] Lee J.C., Quealy K. The 598 People, Places and Things Donald Trump Has Insulted on Twitter: A Complete List // New York Times. 2019, 24 мая. URL: https://www.nytimes. com/interactive/2016/01/28/upshot/donald-trump-twitter-insults.html?ref=politics\&_ $\mathrm{r}=2$ (accessed: 04.06.2019).

[9] Official Twitter of Donald Trump. URL: https://twitter.com/realdonaldtrump (accessed: 04.06.2019).

[10] Siddiqui S. Donald Trump calls Barack Obama the Founder of ISIS // The Guardian. 2016, 11 August. URL: https://www.theguardian.com/us-news/2016/aug/11/donaldtrump-calls-barack-obama-the-founder-of-isis (accessed: 04.06.2019).

[11] Soloviev V., Klepikova E. Donald Trump. Fight for the White House. Moscow: RIPOL Classic, 2016.

[12] Official Twitter of Hillary Clinton. URL: https://twitter.com/hillaryclinton (accessed: 04.06.2019).

[13] The Economist. 2018, 11 January. URL: https://www.economist.com/ printedition/ 2018-01-13 (accessed: 04.06.2019).

[14] Blake A. The First Trump Clinton Presidential Debate Transcript Annotated // The Washington Post. 2016, 27 September. URL: https://www.washingtonpost.com/ news/the-fix/wp/2016/09/26/the-first-trump-clinton-presidential-debate-transcriptannotated/ (accessed: 04.06.2019).

[15] Auslander S. Don't compare Donald Trump to Adolf Hitler. It belittles Hitler // The Washington Post. 2016, 13 September. URL: https://www.washingtonpost.com/ posteverything/wp/2016/09/13/dont-compare-donald-trump-to-adolf-hitler-it-belittleshitler/?utm_term=.4ff82af31de5 (accessed: 04.06.2019).

[16] Ball J., Rusbridger A., Brooke H. et al. Who is Julian Assange? By the people who know him best. URL: https://www.theguardian.com/ media/2012/aug/24/who-is-julianassange (accessed: 04.06.2019).

[17] Booker C. The seven basic plots: why we tell stories. New York: Continuum, 2004.

[18] Lucaites J.L., Condit C.M. Re-constructing Narrative Theory: A Functional Perspective // Journal of Communication. 1985. Vol. 35. No. 4. Pp. 90-108.

[19] Thompson R., Haddock G. Sometimes stories sell: when are narrative appeals most likely to work? // European Journal of Social Psychology. 2012. Vol. 42. No. 1. Pp. 92-102. 


\section{История статьи:}

Дата поступления в редакцию: 28 июля 2019

Дата принятия к печати: 12 сентября 2019

\section{Для цитирования:}

Chernenko J.A. Three faces of Trickster in modern politics: Donald Trump, Alexey Navalny and Julian Assange (Три лика Трикстера в современной политике: Дональд Трамп, Алексей Навальный и Джулиан Ассанж) // Вестник Российского университета дружбы народов. Серия: Литературоведение. Журналистика. 2019. Т. 24. № 4. С. 756-764. http://dx.doi.org/10.22363/2312-9220-2019-24-4-756-764

\section{Сведения об авторе:}

Черненко Юлия Александровна, кандидат филологических наук, эксперт лаборатории образовательной и молодежной журналистики, преподаватель департамента медиа, факультет коммуникаций, медиа и дизайна, Национальный исследовательский университет «Высшая школа экономики». E-mail: juchernenko@hse.ru 